\title{
Main Attributes of Quality and Price Perception for a la Carte Restaurants
}

\author{
Maria Auxiliadora Cannarozzo Tinoco*, Luis Duarte Ribeiro
}

Federal University of Rio Grande do Sul

\begin{abstract}
This paper presents a qualitative study of the main determinants of perceived quality and perceived price as seen by clients of a la carte restaurants. Focus group interviews were conducted covering four types of consumers: couples without children, groups of friends, families, and groups of executives. The main determinants of perceived quality identified in this study were: attributes of the food, service, ambience, waiting time, cleanliness, security, support facilities, menu, attributes of drinks, privacy, accuracy, decor, and confirmation of expectations. On the other hand, the most important determinants of perceived price were: food quality, decor, ambience, service, support facilities, menu, cleanliness, attributes of drinks, portion size, prior expectations, and privacy. Results suggest a strong relationship between determinants of perceived quality and perceived price, an important aspect to be considered by restaurant managers in order to improve the customer satisfaction. The importance of this work lies in its contribution to research carried out in the restaurant industry, since the findings suggest that quality and price attributes are differently prioritized by customers as a function of their reason for using the service. Hence, managers should look into these factors to position their services according to client characteristics.
\end{abstract}

Keywords Services, Perceived Quality, Perceived Price, A La Carte Restaurants

\section{Introduction}

Companies recognize that they can compete more effectively if they distinguish themselves by the quality of services. Customer satisfaction regarding a product or service is strongly influenced by customer assessment of its characteristics, as in[1]. So, service companies must approach their clients to learn their needs and expectations and identify the most important attributes of the service offered.

The growing importance of service sector in the world economic context and the need to retain and attract clients to ensure market survival require that the criteria according to which clients evaluate service excellence be identified. Thus, service providers can prioritize their efforts to meet those attributes considered most important by customers.

Authors agree that in the absence of tangible evidence customer assessment of services depends on dimensions other than those used to judge product quality, as in[2]. The nature of these dimensions has been studied and several researches have targeted developing and testing models for measuring quality in services, based on assessing quality dimensions, commonly deemed as determinants of service quality (e.g.[3],[4],[2],[5-9]). One of the first models for measuring service quality was proposed by[2]. This model is

* Corresponding author:

maria@producao.ufrgs.br (Maria Auxiliadora Cannarozzo Tinoco)

Published online at http://journal.sapub.org/mm

Copyright (C) 2012 Scientific \& Academic Publishing. All Rights Reserved based on comparing perceived service with expected service and the determinants of perceived quality, regardless service type were: (i) access, (ii) communication, (iii) competence, (iv) courtesy, (v) credibility, (vi) reliability, (vii) responsiveness, (viii) security, (ix) tangibles, and (x) customer understanding.

Literature models for service quality put forward various determinants of service quality that can help service managers to establish more appropriate strategies for satisfying their clients. However, each service sector may have determinants that are considered critical to their clients. Therefore, quality determinants may have different degrees of importance for each service category[10].

Besides perceived quality, another factor that affects the behavior of service clients regarding their satisfaction and loyalty is price perception (e.g. $[11,12])$. Service customers find it difficult to judge prices for the vast majority of services offering a large variety of products, as in[13]. To eliminate this difficulty, the term perceived price rather than price is used.

Although customer perception of price has been considered an essential determinant of purchase behavior and product or service choice[14] few researches have studied perceived price. In fact, works found in literature concerning price perception targeted studying the relationship between price, perceived quality, and other determinants of customer satisfaction. Results suggest a positive relationship between price and perceived quality, as in[13]. However, there is a gap in literature regarding factors that give rise to or affect 
price perception for services clients.

\section{Restaurant Services}

Restaurants are a sector presenting a mix between production and service elements, as in[15]. Restaurant clients use three quality elements to judge their service experience: (i) functional, concerning quality of the food, variety of offered items, drinks, ingredients, and so forth; (ii) mechanical, associated with ambience, layout, lighting, decor, physical facilities, and (iii) human, determined by staff performance, behavior and appearance[16].

Some researchers reported food quality (functional dimension) as the most significant predictor of customer assessments and customer satisfaction (e.g.[17],[18]). Reference[19] suggests that ambience or atmosphere (mechanical dimension) and food quality have a decisive role in the final choice of service provider. Customers' expectations of restaurant service are significantly higher when mechanic clues are positive than when they are negative[16].

On the other hand, human quality exerts a greater influence on overall quality perception of a la carte restaurants than does mechanical quality[16]. Functionality is only part of the experience of consuming a service, and a balanced combination of functional, mechanical and human attributes can ensure success of restaurant business, as in[20,21].

Reference[22] determined the factors that explain customer satisfaction in the full service restaurant industry and concluded that service quality (responsiveness), price expectation, and food quality (or reliability) are the major elements of customer evaluation and satisfaction. Responsiveness dimension was the most important to customers, comprising all personal contact attributes of employees with customers and confirming findings of literature for a la carte restaurant services[16].

Since perceived quality and price are two major elements affecting customer evaluation and satisfaction regarding restaurant services, the central objective of this study objective is to identify, through interviews, the attributes that determine quality and price perceptions of a la carte restaurants clients, considering different categories of a la carte restaurant clients.

\section{Research Method}

Research was conducted following a qualitative approach. The technique of focus group interview was selected for gathering data. Interviews with focus groups are used to: generate ideas and opinions from a group of people, gather a significant volume of information in short time, assure flexibility in data collection, and prompt spontaneity through the interaction among participants, as in[23].

The implementation of the focus group technique was divided in two stages: (i) planning and (ii) conduct of interviews. In the planning stage, the objective of the study was clarified and the selection of participants, venue, issues and moderator was accomplished. In conducting the interviews, forms of storing data collected in the interview were defined and the script of the sessions, which should be standard for all sessions, was defined.

The main objective of the study was to identify the main determinants that affect quality and price perception from the point of view of clients of $a$ la carte restaurants. Given that clients' needs and expectations and, consequently, the assessment they make of service quality, vary as a function of their reason for using the service, after preliminary contact with restaurant managers, four categories of consumers were identified: (i) couples without children, (ii) groups of friends, (iii) families, and (iv) executives. This categorization was used as a criterion in conducting the focus groups. Thus, the survey sought to compare the most important attributes for different categories of clients of a la carte restaurants.

The members of focus groups comprised people who can be characterized as active clients of a la carte restaurants, residents at a district capital in Brazil and from social classes $\mathrm{A}$ and $\mathrm{B}$, since most clients of a la carte restaurants belong to these social classes. The interviews were conducted using four focus groups, one for each category of client, according to the strata of sex and age shown in Table 1.

Table 1. Planning of focus groups interviews

\begin{tabular}{|c|c|c|c|c|c|}
\hline \multirow{3}{*}{ Groups } & \multirow{3}{*}{$\begin{array}{l}\text { Categories of } \\
\text { Clients }\end{array}$} & \multicolumn{4}{|c|}{ Age } \\
\hline & & \multicolumn{2}{|c|}{$\begin{array}{c}25 \text { to } 40 \\
\text { years old }\end{array}$} & \multicolumn{2}{|c|}{$\begin{array}{c}\text { over } 40 \\
\text { years old }\end{array}$} \\
\hline & & Female & Male & Female & Male \\
\hline 1 & $\begin{array}{l}\text { Couples with- } \\
\text { out children }\end{array}$ & 2 & 1 & 1 & 2 \\
\hline 2 & $\begin{array}{c}\text { Groups of } \\
\text { friends }\end{array}$ & 1 & 2 & 2 & 1 \\
\hline 3 & Families & 1 & 2 & 2 & 1 \\
\hline 4 & Executives & 2 & 1 & 1 & 2 \\
\hline
\end{tabular}

Table 2. Script of questions for interviewing the focus groups

\begin{tabular}{|l|l|}
\hline Items & Questions \\
\hline $\begin{array}{l}\text { Client char- } \\
\text { acterization }\end{array}$ & $\begin{array}{l}\text { 1. With what frequency is the service used? } \\
\text { carte restaurant? } \\
\text { 3. What are the criteria for the choice of an a la carte } \\
\text { restaurant? }\end{array}$ \\
\hline $\begin{array}{l}\text { Determinants } \\
\text { of perceived } \\
\text { quality }\end{array}$ & $\begin{array}{l}\text { carte restaurant? } \\
\text { 5. What are the main factors that affect service per- } \\
\text { ceived quality? } \\
\text { 6. Which of these factors has greatest and least impact } \\
\text { on quality perception? }\end{array}$ \\
\hline $\begin{array}{l}\text { Determinants } \\
\text { of perceived } \\
\text { price }\end{array}$ & $\begin{array}{l}\text { tion to the service offered by an a la carte restaurant? } \\
\text { 8. What are the main factors that affect service per- } \\
\text { ceived price? } \\
\text { 9. Which of these factors has greatest and least impact } \\
\text { on price perception? }\end{array}$ \\
\hline
\end{tabular}

The number of participants in each group was six, considered sufficient for everyone to have the opportunity to opine on the matter and provide a diversity of ideas, as in[23]. The interviews followed a semi-structured script, with open questions inducing the participation of the interviewees. The structure of the script is shown in Table 2. 
The interviews were conducted in a special room at the University building, which was of easy access to participants and has a physical structure suited to place the interviewees in a circle, which facilitated communication. The sessions lasted approximately one and a half hour, which was enough to gather data allowing everyone to participate.

The sessions were stored on video, which facilitated the identification of each member of the group when they were speaking. Also, an assistant was present, sitting at a side table, taking notes on key interventions.

\section{Results}

\subsection{Description of Interviews}

The interviews were conducted for the four groups identified in Table I. The first group consisted of people who, in most cases, frequent a la carte restaurants in the companionship of their partners (boyfriend, girlfriend, or spouse). The second group was made up of people who, generally, frequent these establishments to meet friends. The third group comprised people who use the services of an a la carte restaurant in the company of their spouse and children (especially young children), and the fourth group was of clients who frequent a la carte restaurants for business purposes (executives). Each group had six participants stratified by gender and age, as per Table 1 .

\subsubsection{Couples without Children}

\section{- Client characterization}

Participants indicated that their frequency of use varies between 5 and 15 times a month. For most participants, the days of greatest use of the service are at weekends. The type of meal they have at a la carte restaurants with their peers is mainly dinner. However, some members said that they also use the service, occasionally, to have lunch at weekends.

Some criteria for the choice of a la carte restaurants indicated by the group were: possibility of trying new dishes and getting to know other establishments, restaurant location, recommendation of friends, and acquaintances and security of the site - mainly related to the presence of parking. What was also noted as a criterion for choosing a la carte restaurants was typical food from a country or region.

\section{- Determinants of perceived quality}

Among the main attributes mentioned that affect quality perception of couples who use the service of a la carte restaurants were: taste of the food, quality of ingredients, sophistication of the menu, elaborateness of recipes, colorful presentation of dishes, service from staff, reception, welcoming ambience with suitable lighting and decor, cleanliness of the site, waiter's knowledge regarding how dishes are prepared and wine characteristics, privacy, well-defined separation of tables for smokers and non-smokers, and availability of dental floss in the restroom. Other attributes mentioned that may negatively affect quality perception were: security ostentatious with armed guards at reception who might scare even the customer, waiting time to enter the dining area, time to place and receive orders, odors from kitchen, and account miscalculations.

Other factors mentioned as attributes presenting less impact on clients' quality perception were: possibility of making a reservation at relatively short notice, location (or dislocation compensated by the benefits offered by the restaurant), and obligation to tip. One of the attributes mentioned that generated divergent opinions was price. However, for most participants, the effect of price on quality perception of a la carte restaurant has hardly any importance.

\section{- Determinants of perceived price}

After analyzing all elements presented before, the group of couples without children considered that the most important concerning price perception were: sophistication of ambience, decor, service from staff, elaborateness of the menu, cleanliness of public area and restrooms, food quality and exquisiteness, exclusivity of certain dishes offered, quality of ingredients and supplies, and table appearance (silverware, table-cloths, glasses, napkin).

Other factors mentioned that may affect price perception (less important) were: privacy, obligation to tip, and site security including parking availability.

\subsubsection{Groups of Friends}

\section{- Client characterization}

The frequency of use of a la carte restaurants indicated by those characterized as groups of friends varied from 2 to 15 times a month. Some use the service during the week with colleagues, and others, only during weekends. Some interviewees reported using a la carte restaurants with friends for lunch and others for dinner. Lunch with friends usually takes place during the week and dinners mainly at weekends.

Among the choice criteria of a la carte restaurants cited by the group were: price of the service, type of food, size of portions, and convenience in location, specially for lunch (for dinner this is not considered a relevant criterion).

\section{- Determinants of perceived quality}

According to participants, the main factors that affect quality perception of a la carte restaurant were: food and drink attributes (temperature, seasonings, ingredients), courtesy of staff, comparison between expected and received service (confirmation of expectations), time taken to serve ordered food and drinks, and service accuracy. Regarding this last item, members of the group mentioned that order errors or miscalculated bills compromise the quality of service offered by restaurants. Other factors cited were: security, layout (i.e., adequate spacing between tables; smokers kept well apart from non-smokers), ambiance odors (food, smoke), cleanliness, support facilities (restroom, tables, chairs), and lighting.

Factors identified by participants as attributes of minor effect on quality perception were: privacy to talk, price, service speed, and kitchen open to visitors. One participant commented that after-sales service offered by some a la carte restaurants can also affect perceived quality, citing as 
examples the concern with clients' complaints and discount offered to non-satisfied customers.

\section{- Determinants of perceived price}

According to respondents, the main factors affecting price perception of a la carte restaurant customers that use the service with friends are: food and drink quality, ambience including decor and support facilities, cost-benefit relationship, and service from staff.

Among the attributes of least effect on clients' price perception, mention was made of: restaurant image - built from advertising and broadcast, size of portions, and presentation of food.

\subsubsection{Families}

\section{- Client characterization}

The group characterized as families frequents a la carte restaurants, on average, one or two times a month. They comment that this type of restaurant is not the most used by families with children, because generally they need a place capable of providing a quick meal including options for all family members. The usual type of meal for families at $a$ la carte restaurants is lunch.

\section{- Determinants of perceived quality}

Among the main factors affecting quality perception and also considered as criteria for choosing a la carte restaurants by families, mention was made of: food (taste, presentation and temperature), variety of dishes (including simple options that children like), service from staff (courtesy, respect and sensitivity), cost-benefit relationship, ambience (pleasant and quiet, with no area for smokers and no strong smells, suitable lighting), physical layout with options offered for children amusement (such as an area with playground and animateur), availability of adequate facilities for children (such as comfortable and safe high chairs), changing room in restrooms, cutlery and glasses and dishes suitable for children, security, presentation of cutlery, table cloths, glasses and dishes, waiting time to be attended and served. This last item was considered particularly important because children do not usually have much patience waiting for food seated at table for a long time. The layout of the dining area was also considered among the factors that affect perceived quality, since parents often need to take a child's push-chair and tables too close does not permit this. Finally, cleanliness of the area and waiter's appearance were also cited as important factors.

Other factors of lesser influence on perceived quality mentioned by the group were: convenience of location, bill accuracy, and size of portions. Regarding the latter, it was added that some restaurants that do not offer smaller portions for children, sometimes have the option of a family dish, which can be shared among all family members, including children. Price was also cited as a factor of lesser effect on perceived quality.

\section{- Determinants of perceived price}

According to participants of the family group, perception of price is formed mainly by: comparison with similar res- taurants (competition), location, visual appearance of the restaurant, ambience sophistication, waiter and other staff's behavior, decor, recommendation from friends, articles in magazines or advertising. Among the main factors that affect price perception of clients who use the service with their family, mention was made of: quality of food, ambience, service, physical facilities, size of portions, decor, and cleanliness.

Attributes of minor effect on the perception of price cited by this group were: elaborateness of the menu and parking availability.

\subsubsection{Executive}

\section{- Client characterization}

The group interviewed, which was characterized as business clients of a la carte restaurants, uses the service with a frequency of 1 to 8 times a month, mostly during working days. The frequency of use depends on the objectives and programming of the executives with their clients. The type of meal that interviewed executives commonly share with their clients is lunch. Lunch-time is more convenient for both the executive and his/her clients. However, occasionally dinners are arranged to celebrate benefits generated from negotiations, on special dates or for presentation of awards and achievements.

According to the executives, the main criteria for choosing a la carte restaurant were: convenience of location, recommendation of third parties, privacy of the location, parking availability, cost-benefit relationship, and client's preference for a specific restaurant or food. Many executives choose a given restaurant because it has been recommended by his/her client.

\section{- Determinants of perceived quality}

The main factors cited by the group that affect perceived quality of executive clients of a la carte restaurants were: presentation of food, temperature of drinks, and elaborateness of dishes. Regarding the latter, comment was made that the menu of a la carte restaurants should offer special dishes that differentiate them, "... carefully prepared and based on singular ingredients and seasonings." Other factors considered as determinants of perceived quality for executive clients were: waiter's behavior (referring mainly to service turn-round time and without inopportune interruptions), variety of menu options, site cleanliness (including restrooms), waiting time (on arrival, for serving food and drinks, and for presentation of the account), smells, privacy and tranquillity, and ambience.

Among the factors of lesser effect on quality perception, from the point of view of the executives interviewed, mention was made of: obligatory tip, price, layout (room for movement), decor, parking availability, and adequacy of support facilities (tables, chairs, glasses, cutlery, crockery and table-cloths, cloth napkins).

\section{- Determinants of perceived price}

According to the participants, the perception of price is formed in the minds of executive clients of a la carte res- 
taurants based on: menu offered, establishment advertising, recommendation of third parties, restaurant's image, clients' past experiences, prior expectations, decor, location, Head Chef reputation, and status of people who frequent the restaurant.

Among the factors of greatest effect on executive clients' perception of price, were cited: service quality and food quality (including taste, appearance, sophistication, variety, and balance), decor, and clients' prior expectations. Also raised as attributes that influence perceived price were: ambience, number and organization of tables, being led to the table, availability of staff to park cars, supporting facilities, facilitating goods (such as, for example, dental floss in the restroom), and privacy of the restaurant. Other attributes of minor effect on price perception also cited by executives were: size of portions, lighting, availability of a wine list, previous experience, and number of staff.

\subsection{Analysis of the Results of the Meetings}

The analysis of data collected was undertaken by comparing the views put forward by the participants of the four focus groups (couples without children, groups of friends, family and executives). This comparison between the groups follows the outline of questions set out in the script in Table 2 .

\subsubsection{Characterization of Clients}

The aim of the first three questions was to characterize the groups interviewed as clients of a la carte restaurants and to settle participants into the subject of discussion. Regarding the frequency of use of a la carte restaurants, large variability in responses of participants of each group was observed, except in the family group, in which most participants indicated a similar frequency of use of the service. Considering the interviewed groups, clients who most frequent a la carte restaurants are couples without children and groups of friends.

The type of meal generally consumed in a la carte restaurants was a characteristic of each group. The group characterized as couples without children indicated that they generally use this service for dinner. The group of friends indicated that they sought this type of establishment both for lunch and for dinner. While the family and executive groups indicated lunch as the usual type of meal partaken in a la carte restaurants.

Regarding the criteria for choosing a la carte restaurant, it may be stressed that most of these criteria were also considered among the attributes that characterize the quality of $a$ la carte restaurants, and among the factors that affect quality and price perception. Other criteria for such a choice, which were characteristic of each group of clients interviewed, were: the group characterized as couples without children highlighted the possibility of trying new dishes and their respect for food from other cultures as their criteria for choosing; for the family group, the main criteria were the options offered for the amusement of children and the prac- ticality of the site, while for executive clients, the preferences of their clients and the availability of tables were the main relevant criteria.

\subsubsection{Determinants of Perceived Quality}

On analyzing questions 4,5 and 6 , concerning quality characteristics of $a$ la carte restaurants and factors that affect perceived quality from the point of view of the groups interviewed, main attributes and other less important factors were identified.

The four groups agree in the following important factors that affect quality perception by clients of a la carte restaurants: food attributes (including taste, presentation, temperature and ingredients), service from staff (courtesy, amiability, respect, discretion, knowledge and sensitivity), ambience (including layout, other people who frequent the restaurant, smells, separation of smokers and non-smokers, size of the site and lighting), waiting time (being led to table, service of meals and drinks and presentation of the bill), and cleanliness of the site.

Table 3. Comparison of determinants of perceived quality among the groups interviewed

\begin{tabular}{|c|c|c|c|}
\hline \multicolumn{4}{|c|}{ Important factors affecting perceived quality } \\
\hline & Groups & & \\
\hline $\begin{array}{c}\text { Couples with- } \\
\text { out children }\end{array}$ & $\begin{array}{c}\text { Group of } \\
\text { friends }\end{array}$ & Family & Executives \\
\hline $\begin{array}{l}\text { Attributes of the } \\
\text { food } \\
\text { Service } \\
\text { Wait time } \\
\text { Cleanliness } \\
\text { Security } \\
\text { Support facili- } \\
\text { ties } \\
\text { Menu } \\
\text { Privacy } \\
\text { Accuracy } \\
\text { Decor }\end{array}$ & $\begin{array}{l}\text { Attributes of the } \\
\text { food } \\
\text { Service } \\
\text { Wait time } \\
\text { Cleanliness } \\
\text { Security } \\
\text { Support facilities } \\
\text { Attributes of } \\
\text { drinks } \\
\text { Confirmation of } \\
\text { expectations } \\
\text { Accuracy }\end{array}$ & $\begin{array}{l}\text { Attributes } \\
\text { of the food } \\
\text { Service } \\
\text { Wait time } \\
\text { Cleanliness } \\
\text { Security } \\
\text { Support } \\
\text { facilities } \\
\text { Menu }\end{array}$ & $\begin{array}{l}\text { Attributes of } \\
\text { the food } \\
\text { Service } \\
\text { Wait time } \\
\text { Cleanliness } \\
\text { Attributes of } \\
\text { drinks } \\
\text { Privacy } \\
\text { Menu }\end{array}$ \\
\hline \multicolumn{4}{|c|}{ Other factors (less important) affecting perceived quality } \\
\hline $\begin{array}{c}\text { Location } \\
\text { Price } \\
\text { Possibility of } \\
\text { booking } \\
\text { Advertising } \\
\text { Wine list } \\
\text { Image }\end{array}$ & $\begin{array}{c}\text { Location } \\
\text { Price } \\
\text { Menu } \\
\text { Kitchen open to } \\
\text { visit } \\
\text { Privacy } \\
\text { After-sales }\end{array}$ & $\begin{array}{l}\text { Location } \\
\text { Price } \\
\text { Size of } \\
\text { portions } \\
\text { Accuracy }\end{array}$ & $\begin{array}{l}\text { Location } \\
\text { Price } \\
\text { Security } \\
\text { Support fa- } \\
\text { cilities } \\
\text { Decor }\end{array}$ \\
\hline
\end{tabular}

Other factors showed some divergences among groups. Security, mainly related to the presence of parking, and supporting facilities (adequacy of tables, silverware, chairs, table-cloths, napkins, restrooms, glasses, facilities for children, and so forth) were considered by the group of couples without children, group of friends and family, as important factors affecting quality perception. However, these attributes were included among those of lesser effect by the group of executives. On the other hand, the menu (including elaborateness of recipes and variety of dishes) was included as an important attribute by the groups of couples without children, families and executives. However, this latter factor was indicated as being of lesser importance by the group of friends. 
Table 3 summarizes the comparison of factors of greater and lesser effect on perceived quality, as indicated by the groups interviewed. It is important to stress that Table 3 shows the attributes affecting perceived quality in the order of general importance, obtained from the average of the groups, not in the order indicated by each individual group. This serves to facilitate visual comparison between the attributes mentioned by each group.

\subsubsection{Determinants of the Price Perceived}

The last three issues raised in the interviews sought to identify the determinants of price perceived by clients of a la carte restaurants. The four groups agree that the following are important factors that affect price perception by clients of a la carte restaurants: food quality, ambience, decor, and service. Support facilities were included as an important attribute by the group of couples without children, groups of friends and family group, but were not considered by the executives.

Table 4. Comparison of determinants of perceived price among the groups interviewed

\begin{tabular}{|c|c|c|c|}
\hline \multicolumn{4}{|c|}{ Important factors affecting perceived price } \\
\hline & Groups & & \\
\hline $\begin{array}{l}\text { Couples } \\
\text { without } \\
\text { children }\end{array}$ & $\begin{array}{l}\text { Group of } \\
\text { friends }\end{array}$ & Family & Executives \\
\hline $\begin{array}{l}\text { Attributes of } \\
\text { the food }\end{array}$ & $\begin{array}{l}\text { Attributes of } \\
\text { the food }\end{array}$ & $\begin{array}{c}\text { Attributes of } \\
\text { the food }\end{array}$ & $\begin{array}{l}\text { Attributes of } \\
\text { the food }\end{array}$ \\
\hline Decor & Decor & Decor & Decor \\
\hline Ambiance & Ambiance & Ambiance & Ambiance \\
\hline Service & Service & Service & Service \\
\hline $\begin{array}{l}\text { Support } \\
\text { facilities }\end{array}$ & $\begin{array}{l}\text { Support } \\
\text { facilities }\end{array}$ & $\begin{array}{l}\text { Support } \\
\text { facilities }\end{array}$ & $\begin{array}{c}\text { Prior } \\
\text { expectations }\end{array}$ \\
\hline Menu & $\begin{array}{c}\text { Attributes of } \\
\text { drinks }\end{array}$ & $\begin{array}{l}\text { Size of } \\
\text { portions }\end{array}$ & Menu \\
\hline Cleanliness & & Cleanliness & Privacy \\
\hline \multicolumn{4}{|c|}{ Other factors (less important) affecting perceived price } \\
\hline Security & Image & Security & Image \\
\hline Privacy & $\begin{array}{l}\text { Size of por- } \\
\text { tions }\end{array}$ & Menu & $\begin{array}{c}\text { Size of por- } \\
\text { tions }\end{array}$ \\
\hline Wine list & & Competition & Wine list \\
\hline \multirow[t]{4}{*}{$\begin{array}{c}\text { Obligation of } \\
\text { tip }\end{array}$} & & Location & Location \\
\hline & & Advertising & Advertising \\
\hline & & $\begin{array}{c}\text { Appearance of } \\
\text { the staff }\end{array}$ & $\begin{array}{c}\text { Number of } \\
\text { staff }\end{array}$ \\
\hline & & & $\begin{array}{l}\text { Previous } \\
\text { experience }\end{array}$ \\
\hline
\end{tabular}

The groups of couples without children and executives also indicated the menu as an important factor that affects price perception. However, the family group considered this attribute among those of lesser importance. On the other hand, there was convergence between the group of couples without children and the family group in that they considered cleanliness of the site among the important factors that affect clients' perception of price. Other factors of importance mentioned by the groups, without there being any convergences among them, were: attributes of drinks, size of portions, and privacy.
Table 4 summarizes the comparison of factors of greater and lesser effect on perceived price, as obtained from interviews with the focus groups. As obtained from perceived quality, the attributes affecting perceived price are presented in the order of general importance, obtained from the average of the groups, and not in the order given by each individual group.

\subsection{Interpretation of the Results}

\subsubsection{Determinants of Perceived Quality}

The analysis of the results obtained in the various groups revealed agreement on the main determinants of perceived quality in a la carte restaurants. The results of this study confirm findings from restaurant industry literature regarding the influence of food quality, service and environment on customer's perceived quality[24]. The differences among the groups interviewed are basically related to the order of importance of the factors that affect clients' quality perception. These differences are due mainly to the particular needs of each group, which cover couples without children, groups of friends, families, and executives. Some of the most striking divergences are presented below:

- Couples without children using the service of a la carte restaurants perceive service quality mainly through food attributes, service and ambiance. This type of customer looks for restaurants offering a high quality meal that is full of flavor and sophisticated, in a welcoming and tranquil ambience, where an out-of-the-ordinary service is provided.

- Friends give most importance to courtesy of staff and pleasant ambience.

- Families assign greatest importance to excellence of food, with options for all members, including children, speed of service, and support facilities for children.

- Executives assign greatest importance to menu, waiter's behavior and rapid turn-round in service.

Figure 1 shows a model summarizing quality determinants of a la carte restaurants, as perceived by clients, identified through focus group interviews. The most important factors are shown in bold.

It is observed in Figure 1 that all determinants of perceived quality, identified by clients of a la carte restaurants, may be considered within the quality dimensions put forward in the first proposal of $[2]$. The model proposed for the determinants of perceived quality is based on this theoretical model. However, the following modifications were made, based on results from this study and in other works from literature:

- The ten quality dimensions and the attributes identified in the context of a la carte restaurants are presented as direct determinants of the perceptions of service, and indirectly affect perceived quality of service. In the theoretical model proposed by[2], these determinants also affect expectations. The model proposed does not consider these dimensions as determinants of expectations, since the main factors that influence clients' prior expectations according to several authors are: word-of-mouth communication, personal needs, past experiences, and external communication or advertising 
(e.g.[6],[25]).

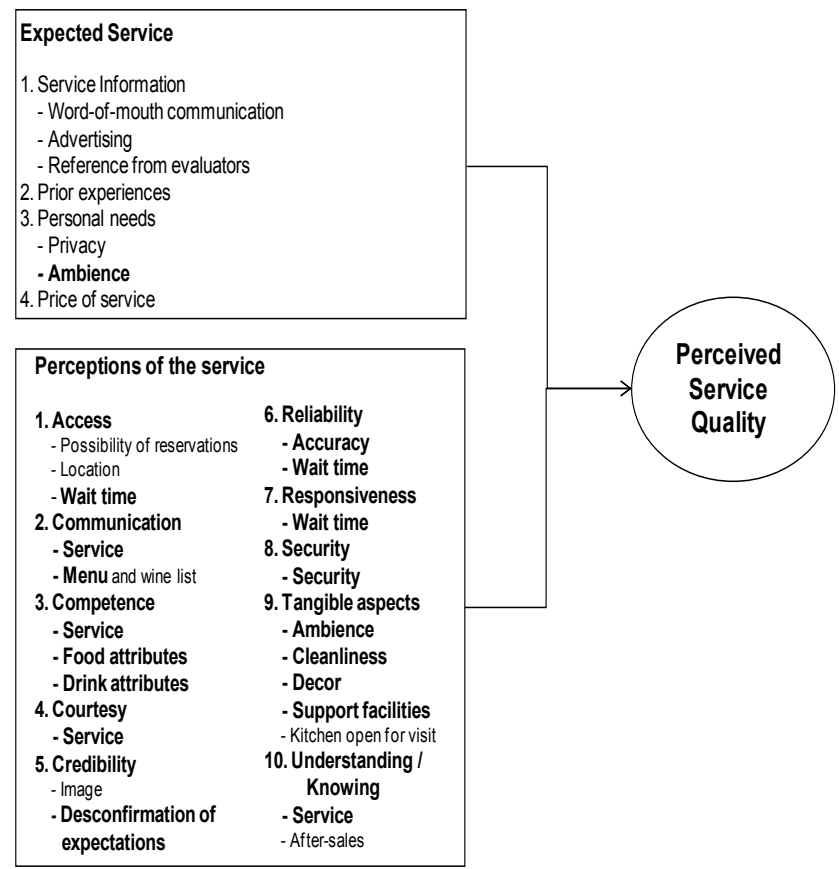

Figure 1. Determinants of the quality perceived by clients of a la carte restaurants

- According to results of the interviews, advertising and price do not have a noticeable (direct) effect on perceived quality. Thus, they were included as determinants of expected service. These elements were not present in proposed model of[2]. Advertising and reference from experts, in addition to word-of-mouth communication, are, for clients, the key sources of information regarding restaurant's service. Through this information, previous experiences and personal needs, expectations are generated.

- Price was not considered as a direct determinant of quality, even though it had a strong relationship with it, by affecting it indirectly through clients' expectations[4]. Competitors' prices, or any other anchor prices that the client has, through previous experience, recommendation or reference, generate service expectations, which are compared with the perception of performance thus forming perceived quality.

Although the model proposed by[2] covers most determinants of perceived quality for clients of a la carte restaurants, the importance of this study lies in the fact that specific attributes used by clients to evaluate the service of a la carte restaurants are identified. Attributes which are important for evaluating a specific type of service are not considered within the dimensions of quality proposed in literature all-purpose models.

\subsubsection{Determinants of Perceived Price}

With regard to determinants of perceived price that were identified in the study, convergences were observed in the main factors mentioned by the groups of clients of a la carte restaurants. Just as with the determinants of perceived quality, the few differences among groups are due mainly to particular characteristics of couples without children, groups of friends, families and executives.

The factors identified through focus groups and considered as determinants of price perceived by clients of $a$ la carte restaurants are shown in Figure 2.

The proposed model of the determinants of perceived price, shown in Figure 2, suggests that price perceived by clients of the a la carte restaurants is formed based on the comparison between the price expected or the anchor one and the real price of the service. The expected price is influenced by a number of attributes or determinants. The factors considered of greatest importance are marked in bold.

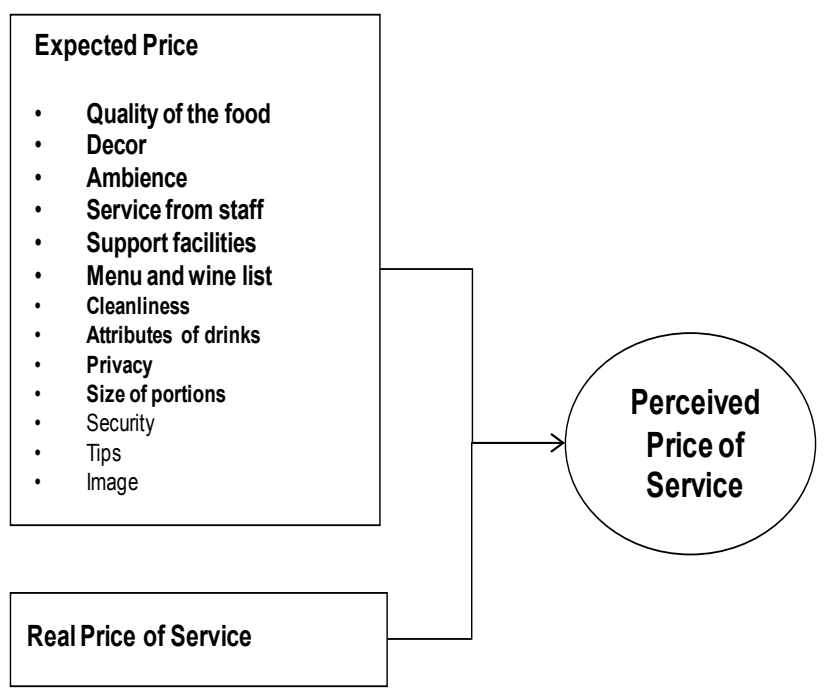

Figure 2. Determinants of price perceived by clients of a la carte restaurants

On analyzing Figures 1 and 2, it is observed that most of the important determinants of perceived price coincide with important determinants of quality perceived by clients of $a$ la carte restaurants. This result confirms the study conducted by $[12,13]$, on the relationship between the dimensions of service quality and price perceived by clients. The results obtained in the study of these authors indicate that quality dimensions contemplated in the SERVQUAL instrument affect the price perceived for some of the types of services that they evaluate. Therefore one could say that for a la carte restaurant service, the main determinants of perceived quality also affect price perception. This relationship between quality and price perceived has not been well determined by service marketing researchers, it seems that no clear links have been established between these two variables for satisfaction research. According to[12] quality and price are actually the two most important factors when customers decide to purchase the service in the context of student food service. In this sense, this study contributes to literature researches confirming the relationship between perceived price and perceived quality in a la carte restaurant's services and also highlighting the importance of considering these constructs in planning the services.

\section{Conclusions}


The use of focus groups allowed the main determinants of quality perceived and price perceived by clients of a la carte restaurants to be identified, taking into consideration the opinions of different groups of clients (couples without children, groups of friends, families, and executives).

Although there are some divergences regarding the order of importance of the factors affecting quality and price perception for clients of a la carte restaurants, the existence of a number of common important determinants for the four groups of clients investigated was verified.

The main determinants of perceived quality identified through the focus group interviews were: food attributes, service, ambience, waiting time, cleanliness, security, support facilities, menu, privacy, drink attributes, confirmation of expectations, accuracy, and decor. Among the attributes of lesser influence on perceived quality were identified: location, price, possibility of making reservations, advertising, wine list, and image.

A model was proposed to represent quality perceived in $a$ la carte restaurants. This model was based on that proposed by[2], and included some modifications in the design and greater detailing of the elements of the model (which were specified for the service rendered by a la carte restaurants).

The main determinants of perceived price, according to the results of the study were: quality of the food, decor, ambience, service, support facilities, menu, cleanliness, attributes of the drinks, size of portions, prior expectations, and privacy. Other attributes identified as having lesser effect on perception of price by clients of a la carte restaurants were: security, wine list, tip, image, competitors' price, location, and advertising. Although scarce in the literature, studies targeted on identifying the determinants of perceived price and the results of this research suggest there is a relationship between the determinants of perceived quality and price perceived by clients of a la carte restaurants, as in[12]. The link between these two variables is an important aspect to be considered by restaurant managers in order to improve the customer satisfaction.

The implications of these findings for restaurant managers are very meaningful because the findings are based on customer's perception. This study has identified a number of key service attributes that are important to restaurant customers and that are directly or indirectly involved with service delivery.

These findings also suggest that such quality attributes are differently prioritized by customers as a function of their reason for using the service. Hence, managers should look into these factors that would affect customer judgments of quality and price to position their services according to client characteristics.

One of the main restrictions of this study is that the results obtained for the determinants of perceived quality and perceived price are specific to the type of service under study ( $a$ la carte restaurants) and cannot be generalized to other types of services without the due adaptations. A second limitation concerns the applied methodology. The reliability of focus groups is greater when multiple groups are conducted in several places, with the inclusion of data from other sources, or when they are complemented by the application of a quantitative technique. Further studies contemplating the use of quantitative methods are under development and will be the subject of a future publication.

\section{REFERENCES}

[1] Zeithaml, Valarie A. and Bitner, Mary Jo (2000), Service Marketing: integrating customer focus across the firm, 2nd ed, McGraw-Hill Education, 656 p.

[2] Parasuraman, A.; Zeithaml, Valerie A. and Berry, Leonard L. (1985), "A conceptual model of service quality and its implications for future research", Journal of Marketing, 49 (Autumn), (4), 41-50.

[3] Gronroos, Christian A. (1984), "Service Quality Model and its marketing implications", European Journal of Marketing, $18(4), 36-44$.

[4] Gronroos, Christian A. (2007), Service Management and Marketing: Customer Management in Service Competition, 3rd ed., England: John Wiley \& Sons, 483 p.

[5] Cronin, J. J. and Taylor, S. A. (1992), "Measuring Service Quality: a reexamination and extension", Journal of Marketing, 56 (July) (3), $55-68$.

[6] Gianesi, Irineu G. N. and Corrêa, Henrique Luiz (1994), Administração Estratégica de Serviços: operações para a satisfação do cliente, São Paulo: Atlas, 233 p.

[7] Johnstons, Robert (1995), "The determinants of service quality: satisfiers and dissatisfiers", International Journal of Service Industry Management, 6 (5), 53 - 71.

[8] Carrillat, François A., Jaramillo, Fernando and Mulki, Jay P. (2007), "The validity of the SERVQUAL and SERVPERF scales: A meta-analytic view of 17 years of research across five continents" International Journal of Service Industry Management, 18 (5), 472-490.

[9] Ling, K. C., Chai, L. T. and Piew, T. H. (2010), "The 'Inside-out' and 'Outside-in' Approaches on Students' Perceived Service Quality: An Empirical Evaluation”. Management Science and Engineering, 4 (2), 01-26.

[10] Faganel, A. (2010), "Quality Perception Gap Inside the Higher Education Institution”. International Journal of Academic Research, 2 (1), 213-215.

[11] Bei, Lien-Ti and Chiao, Yu-Ching (2001), "An Integrated Model for the Effects of Perceived Product, Perceived Service Quality, and Perceived Price Fairness on Consumer Satisfaction and Loyalty", Journal of Consumer Satisfaction, Dissatisfaction and Complaining Behavior, 14.

[12] Liang, Xi; Zhang, Shuai (2009), "Investigation of customer satisfaction in student food service". International Journal of Quality and Service Sciences, 1 (1), 113-124.

[13] Chen, Injazz J.; Gupta, Atul and Rom, Walter (1994), “A study of price and quality in service operations", International Journal of Service Industry Management, 5 (2), 23-33.

[14] Padula, Giovanna and Busacca, Bruno (2005), "The asym- 
metric impact of price-attribute performance on overall price evaluation", International Journal of Service Industry Management, 16 (1), 28-54.

[15] Israeli, Aviad and Barkan, Rachel (2004), "Developing a framework for rewards in combined production/service businesses: The case of tipping in the restaurant industry", International Journal of Service Industry Management, 15 (5), 444-459.

[16] Wall, Eileen A. and Berry, Leonard (2007), "The combined effects of the physical environment and employee behavior on customer perception of restaurant service quality", Cornell Hotel and Restaurant Administration Quarterly, 48 (1), 59 69.

[17] Namkung, Young and Jang, SooCheong (Shawn) (2007), "Does food quality really matter In restaurants? Its impact on customer satisfaction and behavioral intentions", Journal of Hospitality \& Tourism Research, 31 (3) August, 387-410.

[18] Liu, Yinghua and Jang, SooCheong (Shawn) (2009), "Perceptions of Chinese restaurants in the U.S.: What affects customer satisfaction and behavioral intentions?", International Journal of Hospitality Management, 28, 338-348.

[19] Kivela, Jak`sa Jack (1997), "Restaurant marketing: selection and segmentation in Hong Kong", International Journal of
Contemporary Hospitality Management, 9 (3), 116-123.

[20] Parsa, H. G.; Self, J. T.; Njite, D. and King, T. (2005), "Why restaurants fail", Cornell Hotel and Restaurants Administration Quarterly, 46 (3), $304-323$.

[21] Abiodun, A. J. (2010), "Patients' Satisfaction with Quality Attributes of Primary Health Care Services in Nigeria". Journal of Health Management, 12 (1), 39-54.

[22] Andaleeb, Syed Saad and Conway, Carolyn (2006), "Customer satisfaction in the restaurant industry: an examination of the transaction-specific model", Journal of Services Marketing, 20 (1), 3-11.

[23] Fern, E.F. (1982), "The use of focus groups for idea generation: The effects of group size, acquaintanceship and moderator on response quantity and quality", Journal of Marketing Research, 19, 1-13.

[24] Liu, Y., Jang, S. (2009), "Perceptions of Chinese restaurants in the U.S.: What affects customer satisfaction and behavioral intentions?" International Journal of Hospitality Management $28,338-348$.

[25] Fornell, Claes; Johnson, Michael D. and Anderson, Eugene W. (1996), "The American Customer Satisfaction Index: Nature, purpose, and findings", Journal of Marketing, 60 (Oct.) (4), 7-12. 